\title{
ORIGINALS
}

\section{Effects of Norepinephrine, Theophylline and Dibutyryl Cyclic AMP on in vitro Lipolysis of Human Adipose Tissue in Obesity*}

\author{
F. A. Gries, M. Berger, M. Neumann, H. Preiss, H. Lmebermeister, C. Hesse-Wortmann, and K. Jahnke \\ Second Medical Clinic and Diabetes Research Institute, University of Düsseldorf, Düsseldorf, Germany
}

Received: August 14, 1971, accepted: October 13, 1971

Summary. Lipolysis (release of glycerol and free fatty acids) of subcutaneous human adipose tissue in vitro has been investigated in relation to relative body weight and fat cell size. Studying 86 persons, there was a highly significant logarithmic relation between relative body weight, fat cell size and lipid content of subcutaneous adipose tissue obtained from the abdominal region. Even in extreme obesity a mean fat cell diameter of $135 \mu$ was generally not exceeded. In these cases overweight is due to hypertrophy as well as hyperplasia of adipose tissue. The basal FFA and glycerol release, calculated on the basis of the lipid content, did not significantly differ in normal and overweight persons. The lipolysis of the individual cell increased, however, with increasing cell diameter. The quotient of resterification (FFA release: glycerol release) was significantly lower in obesity. - When lipolysis was stimulated with norepine. phrine, theophylline or dibutyryl-cyclic AMP, the dose response relations were similar in obesity and normal weight. - The stimulation of lipolysis, expressed as $\%$ of baseline, was diminished in obesity. Stimulation with dibutyryl-eyclic-AMP was negatively correlated to the cell diameter. - The absolute release of metabolites per fat cell after stimulation with norepinephrine, theophylline or dibutyryl-cyclic AMP was positively correlated with the fat coll diameter. - Addition of glucose resulted in an increment in glycerol release and an inhibition of FFA release. However, the correlation of lipolysis with fat cell diameter was not affected. - The observations suggest that large fat cells are provided with additional total lipase. Under basal conditions the relation of inactive prolipase to active lipase seemed to change in favour of the active enzyme.

Effets de la noradrénaline, de la théophylline et du dibutyryl AMP cyclique sur la lipolyse in vitro du tissu adipeux humain dans l'obésité

Résumé. Le but de ce travail est d'examiner si la lipolyse (libération de glycérol et d'acides gras libres) du tissu adipeux humain sous-cutané étudié in vitro est affectée par l'excès ou le déficit pondéral et par la taille des adipocytes. Chez 86 sujets, une relation très étroite a pu être établie entre l'excès ou le déficit pondéral d'une part, et le logarithme de la teneur en lipides ou lo logarithme du diamètre moyen des adipocytes du tissu adipeux sous cutané abdominal d'autre part. Cependant, même en cas d'adiposité extrême le diamètre moyen de l'adipocyte ne dépasse pas $135 \mu$. Dans ces cas, l'obésité dépend à la fois d'une hypertrophie et d'une hyperplasie du tissu adipeux. La libération basale d'acides gras et de

* The results were presented in part at the Fifth Congress of the German Diabetes Association, Bad Godesberg (Berger et al. 1970) and at the Seventh Congress of the International Diabetes Federation, Buenos Aires (Jahnke et al. 1970). glycérol dans le milieu d'incubation n'est pas affectée par la surcharge pondérale, si l'on se réfère à la teneur en lipides du tissu adipeux. Par contre, cette libération d'acides gras et de glycérol est significativement plus grande si l'on se réfère au diamètre moyen des cellules. Dans l'obésité, la libération d'acides gras libres est proportionellement plus faible que celle de glycérol. Une augmentation de la lipolyse a pu être obtenue par l'adjonction au milieu d'incubation de nor-adrénaline, de théophylline et de dibutyryl-AMP cyclique. La relation dose-effet fut comparable que le tissu adipeux provienne de sujets de poids normal ou d' individus obèses. Néanmoins, exprimée en \% des valeurs de base, la stimulation de la lipolyse est plus faible chez les patients obèses. Une corrélation négative entre la réponse lipolytique au dibutyryl-AMP cyclique et le diamètre des adipocytes a été observée. La quantité absolue de glycérol ou d'acides gras libérés en présence de noradrénaline, de théophylline ou de dibutyryl-AMP cyclique était en corrélation positive avec le diamètre des adipocytes. Bien que le glucose stimule la libération de glycérol et inhibe la libération d'acides gras libres, ces effets du glucose n'ont pu être mis on relation avec lo diamètre cellulaire moyen. - Nos observations nous permettent de conclure que les adipocytes de grande taille possèdent une quantité supplémentaire do lipase ot que dans les conditions basales la proportion de lipase active dans ces cellules est vraisemblablement plus élovée.

Der Einfluß von Norepinephrin, Theophyllin und $D i$ butyryl-cyclo-AMP auf die in vitro Lipolyse des menschlichen Fettgewebes bei Fettsucht.

Zusammenfassung. Die Lipolyse (Freisetzung von Glycerin und freien Fettsäuren) des subcutanen mensch. lichen Fettgewebes in vitro wurde in Abhängigkeit vom relativen Körpergewicht und der Fettzellgröße untersucht. Bei $\mathbf{8 6}$ Personen bestanden hochsignifikante logarithmische Beziehungen zwischen relativem Körpergewicht, Fettzelldurchmesser und Lipidgehalt des subcutanen Fettgewebes der Bauchregion. Ein mittlerer Fettzelldurchmesser von $135 \mu$ wurde auch bei extremer Adipositas praktisch nie überschritten. Adipositas ist in diesen Fällen auf Hypertrophie und Hyperplasie des Fettgewebes zurückzuführen. - Die basale Freisetzung von Glycerin und freien Fettsäuren bezogen auf den Lipidgehalt war bei Norm- und Übergewicht nicht signifikant unterschieden. Die Metabolitfreisetzung der Einzelzelle nahm jedoch mit wachsendem Zelldurchmesser zu. Der Lipolysequotient $Q$ (Verhältnis FFS-Freisetzung: Glycerinfreisetzung) war bei Adipositas signifikant kleiner. Die Lipolyse wurde durch Norepinephrin, Theophyllin und Dibutyryl-cyclo-AMP stimuliert. Die Konzentrationsabhängigkeit der Effekte war bei Norm - und Übergewicht ähnlich. - Die Stimulierbarkeit der Lipolyse in Prozent des Basalwertes war bei Adipositas vermindert. Es bestand eine negative Korrelation der Stimulierbarkeit durch Dibutyryl-cyclo-AMP zum Zelldurchmesser. Die 
absolute Metabolitfreisetzung der Fettzelle bei Stimulation mit Noradrenalin, Theophyllin oder Dibutyrylcyclo-AMP nahm mit steigender Zellgröße signifikant zu. - Zusatz von Glucose führte zur Steigerung der Glycerinfreisetzung und zur Hemmung der FFS-Freisetzung, die Korrelation der Lipolyse zum Zelldurchmesser wurde dadurch nicht wesentlich verändert. - Diese Beobachtungen lassen den Schluß zu, daß große Zellen mit zusätz- licher Gesamtlipase ausgestattet sind und daß unter Basalbedingungen das Verhältnis inaktiver Prolipase zur aktiven Lipase zugunsten des aktiven Enzyms verschoben ist.

Key words: Human adipose tissue, fat cell size, obesity, lipolysis, reesterification, norepinephrine, theophylline, DB-C-AMP.
Obesity is the consequence of hyperplasia and hypertrophy of adipose tissue (Hausberger, 1965; Gries et al., 1970). Investigations performed on obese mice have shown that lipogenesis and lipid mobilisation of the fat cell are apparently related to these morphological changes (Mayer, 1965; Herberg et al., 1970). Investigations in vitro of catecholamine-induced lipolysis of human adipose tissue in obesity resulted in contradictory observations and interpretations (Mosinger et al., 1965; Björntorp and Hood, 1966; Preiss et al., 1967; Thamer, 1969; Faulhaber et al., 1969; Goldrick and McLoughlin, 1970), the greater part of which can be explained by the differences in reference systems.

In the present study the regulation of lipolysis in the adipose tissue of obese subjects was analysed by investigating the effect of different lipolytic agents, which activate adipose tissue lipases at different sites, and by taking into consideration different reference systems.

\section{Materials and Methods \\ 1. Patients}

The morphology of fat cells was investigated in 86 subjects, 45 women and 41 men aged from 17 to 73 years with different relative body weight (Broca index ${ }^{1} 0.52$ to 3.36 ). The tissue samples were obtained by biopsy (see below) or at the beginning of abdominal surgery. All tissue samples were taken from the subcutaneous adipose tissue of the abdominal region.

Metabolic assays were performed with tissue obtained by biopsy from two groups:

a) 19 normal male subjects with ages ranging from

20 to 30 years and a Broca index between 0.9 and 1.1 ;

b) 19 overweight patients, 14 men and 5 women, with ages ranging from 20 to 30 years and a Broca index between 1.28 and 3.36 .

The subjects did not show any evidence of endocrinopathies, manifest diabetes mellitus (the controls were also screened for subclinical diabetes mellitus) or inflammatory processes. All subjects had been instructed to ingest $100 \mathrm{~g}$ of glucose per os, in addition to their usual food intake, 1 day before biopsy. According to the results of earlier experiments it was not necessary to consider men and women separately (Berger, 1970).

\footnotetext{
1 Broca index $=\frac{\text { actual weight }}{\text { normal weight according to Broca. }}$
}

\section{Biopsy and preparation of adipose tissue}

Adipose tissue was obtained from the left lower quadrant of the abdominal region after an overnight fast using local anaesthesia which was achieved by intracutaneous infiltration with $0.5 \%$ novocain, thus avoiding contact between fat cells and the anaesthetic (Preiss et al., 1967). The tissue was transferred to Krebs-Ringer bicarbonate buffer (KRB) at $37^{\circ} \mathrm{C}$. Sections of adipose tissue devoid of gross amounts of connective tissue, with a thickness of less than $2 \mathrm{~mm}$ were prepared carefully. All incubations were performed in Krebs-Ringer bicarbonate buffer, with $4 \mathrm{~g}$ albumin per $100 \mathrm{ml}$, at $37^{\circ} \mathrm{C}$ in a metabolic incubator, with a shaking frequency of 75 to 80 per minute.

During a pre-incubation of 1 hour, the medium contained 5.55 mM glucose. Following this pre-incubation, the pieces of adipose tissue were washed with glucose-free medium and approximately $50 \mathrm{mg}$ of tissue transferred to $1 \mathrm{ml}$ of fresh medium with or without $5.55 \mathrm{mM}$ glucose. Immediately before the main incubation and before adding the tissue, lipolytic agents were added to the medium as indicated. The main incubation was carried out for $2 \mathrm{~h} \mathrm{in} 2 \mathrm{ml}$ plastic vessels. Thereafter, the incubation flasks were placed in iced water for $20 \mathrm{~min}$ in order to equilibrate extraand intracellular concentrations of free fatty acids (FFA) and glycerol. Vaughan (1962) has pointed to possible errors when the metabolites in the tissues are neglected, especially when investigating small tissue samples. In our control experiments, the concentration of FFA and glycerol in the incubation medium increased by diffusion out of the tissue by about 4 to $7 \%$ during this period.

The tissue was extracted (Folch et al., 1957) and the amount of esterified acids (EFA) determined in the extracts (Rosenthal et al., 1959). In the incubation medium, FFA were determined colorimetrically by a modification of the method of Itaya and Ui (1965), according to Herberg and Hesse-Wortmann (1969), and glycerol was determined by the glycerol kinase reaction, fluorimetrically (Berger 1970) or according to Kreutz (1962). The release of metabolites was calculated per $\mathrm{g}$ of adipose tissue wet weight, per mMol EFA of the tissue or per $10^{5}$ cells. All incubations and analyses were done in duplicate.

\section{Determination of the cell number of tissue slices}

Isolated fat cells were obtained from a separate part of the same biopsy using Rodbell's technique 
(1964) and stained with methylene blue. From a homogeneous suspension of these cells a sample was transferred to a siliconized chamber of about $5 \mu$ height consisting of microslide, silicon grease and cover glass and the diameter of 100 cells was determined with an eye piece microscope. Cell volume and lipid content of the individual cells were evaluated (Zinder et al., 1967) and the arithmetical mean used for further calculations. The cell content of the incubated tissue was calculated by dividing the lipid content of the tissue by the mean lipid content of the fat cells.

\section{Reagents}

Krebs-Ringer bicarbonate buffer was prepared with half the amount of calcium. Albumin (crystalline human albumin ("reinst") was purchased in one batch from the Behringwerke, Marburg/Lahn and collagenase from the Worthington Biochemical Corporation, Freehold, New Jersey. The following lipolytic substances were applied: Dibutyryladenosine-3', 5'-monophosphate, cyclic (monosodium salt), Boehringer 15205 NAAT (DB-c-AMP), theophylline "reinst" Merck, No. 8403 and arterenol (L-norepinephrine), Farbwerke Hoechst, Hoechst.

\section{Statistics}

Student's t-test was used for statistical evaluation. Indicated are mean values and standard deviations (Mean $\pm \mathrm{SD}$ ) or standard error of the mean (Mean \pm SEM). In the case of linear regression functions, the dispersion $s_{y}, x$, the coefficient of correlation $r$ as well as the tolerance and confidence limits are indicated.

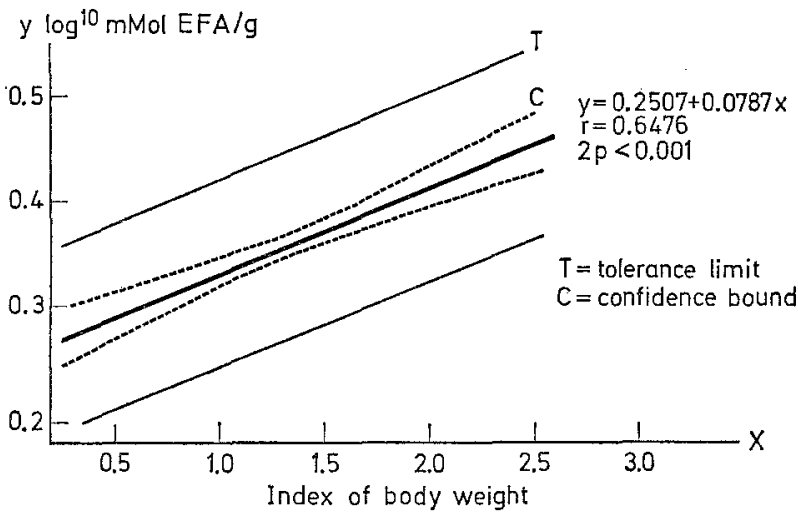

Fig. 1. Relation between the amount of esterified fatty acids (EFA) per $\mathrm{g}$ wet tissue and the relative body weight according to Broca (Broca index BI $1.0=$ normal weight). Indicated are the logarithmic function of correlation, confidence and tolerance limits. $n=86$

\section{Results} weight

Lipid content and cell size in relation to relative body

In the adipose tissue of 18 normal weight and 17 overweight subjects the EFA content was $1.98 \pm 0.32$ $\mathrm{mMol}$ and $2.49 \pm 0.26 \mathrm{mMol} / \mathrm{g}$ tissue wet weight re- spectively. The difference between normal and overweight subjects was significant $(p<0.001)$. There was a significant correlation of the logarithm of the EFA content of the adipose tissue with the Broca index of the subjects (Fig. 1).

The mean fat cell diameter of 86 subjects of different relative body weight was related to the weight index (Fig. 2). The mean fat cell diameter increased with augmenting relative body weight. However, even in extreme obesity a mean value of $135 \mu$ was not exceeded

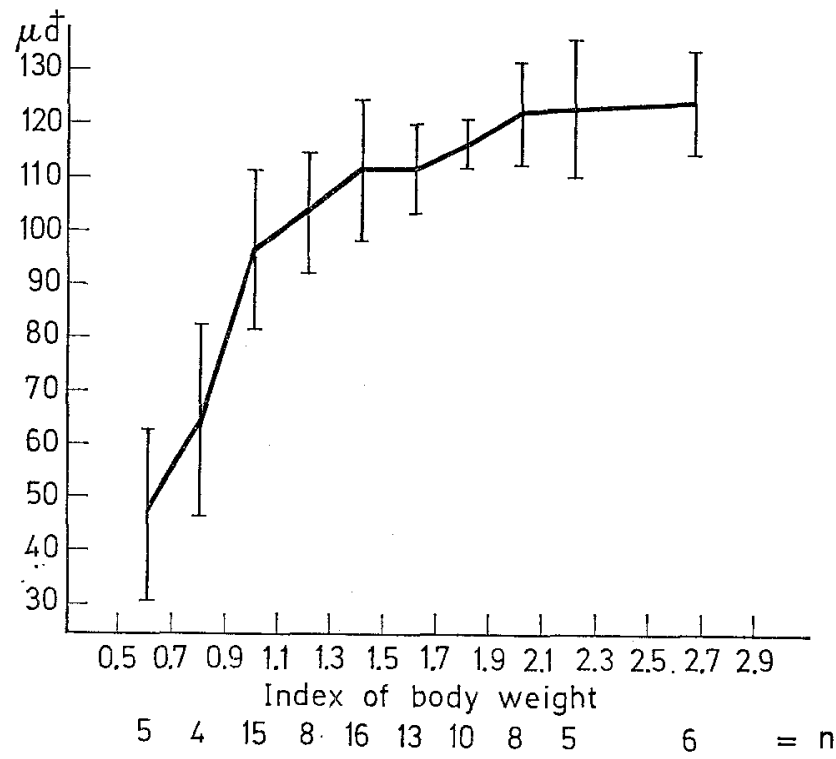

Fig. 2. Fat cell diameter (d) in subjects of different relative body weight. $\mathrm{BI}=$ Broca index, mean $\pm \mathrm{SD}, n=86$

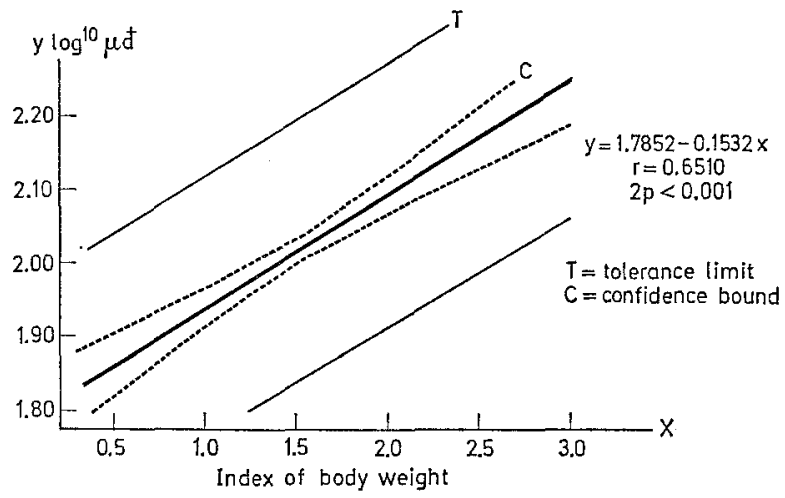

Fig. 3. Relation between the fat cell diameter d and the relative body weight according to Broca (Broca index). Indicated are the logarithmic function of correlation, confidence and tolerance limits. $n=86$

even if some individual cells presented a maximal diameter of $200 \mu$. This asymptotic reaction of the curve resulted in a correlation of the logarithm of the mean fat cell diameter to the relative body weight (Fig. 3).

\section{Basal lipolysis in relation to relative body weight}

If basal release of glycerol and FFA was calculated per lipid content of the incubated tissue, no difference 
BASAL
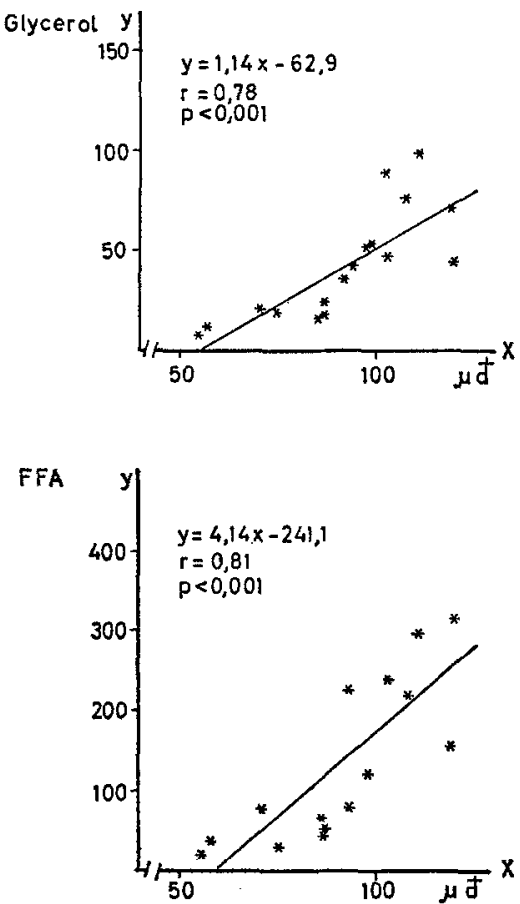

NOREPINEPHRINE $\quad 0,1 \mu \mathrm{g} / \mathrm{ml}$
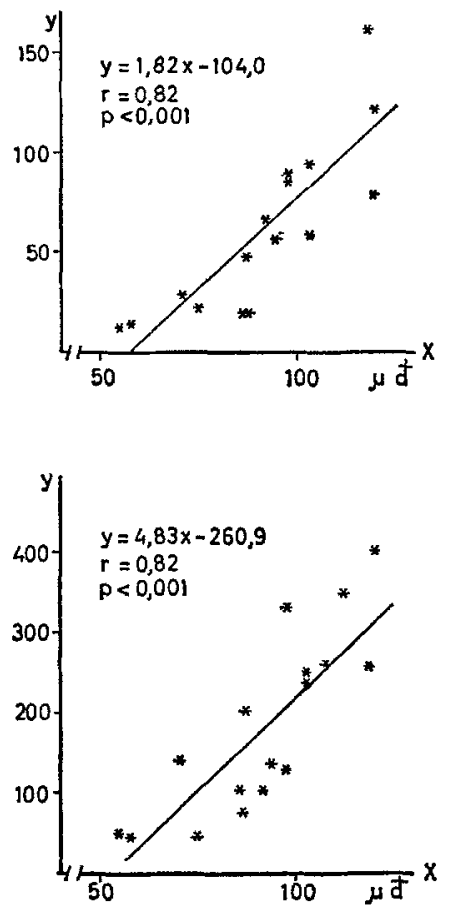
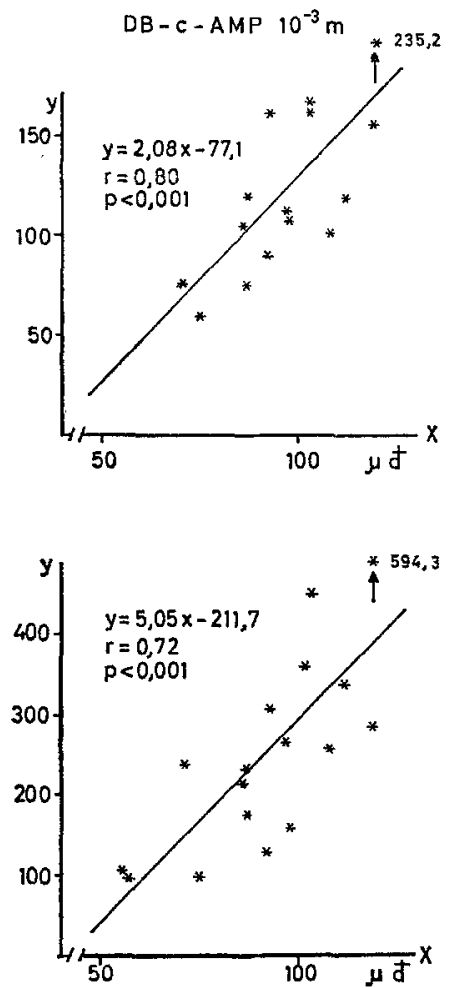

Fig. 4a. Basal and stimulated glycerol and FFA release from adipose tissue pieces in relation to fat cell diameter đ Indicated is the release in nmol $/ 10^{5}$ cells $/ 2 \mathrm{~h}$. Medium: KRB buffer, $4 \mathrm{~g} \%$ albumin, glucose free, additions as indicated
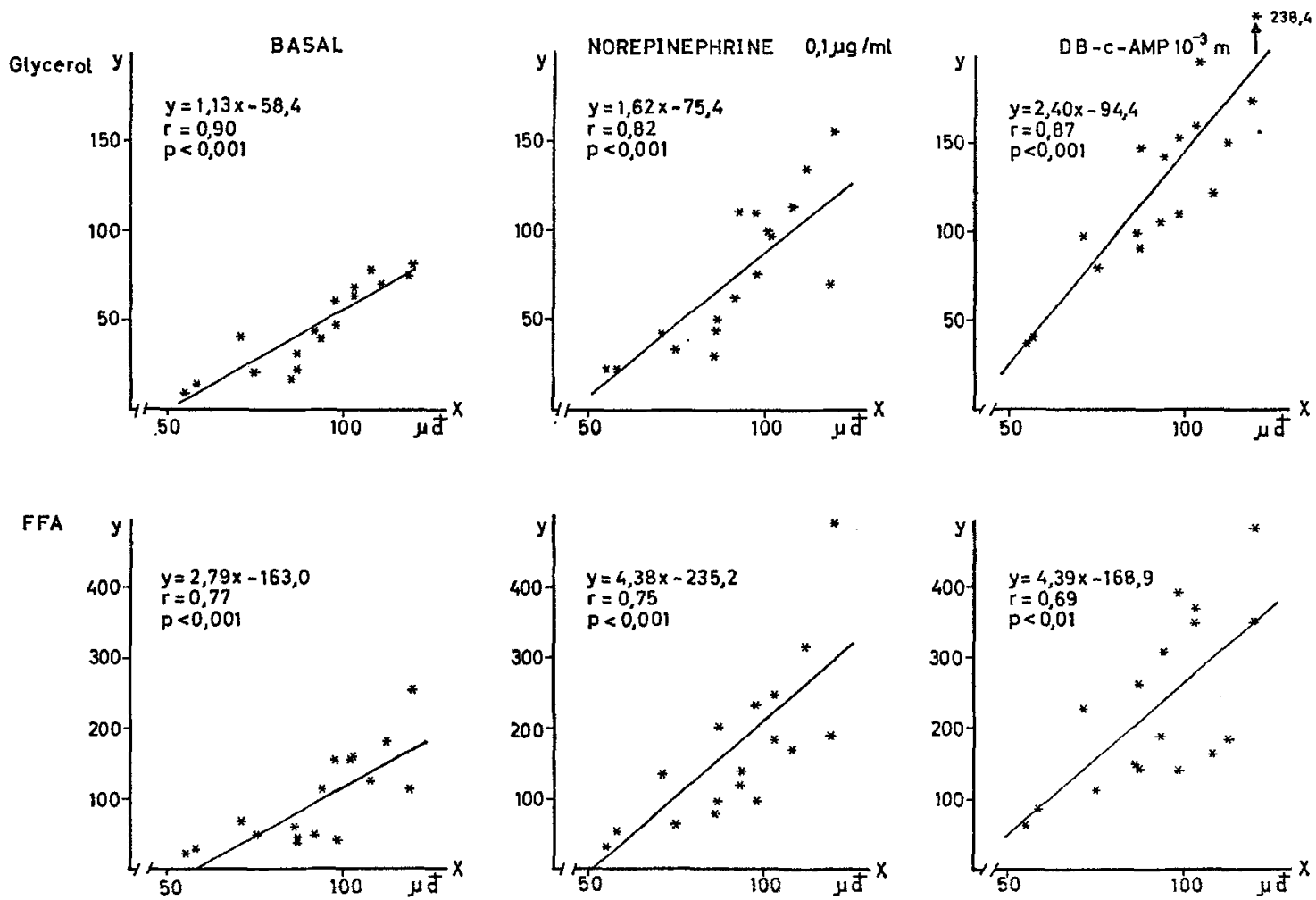

Fig. 4 b. Basal and stimulated glycerol and FFA release from adipose tissue pieces in relation to fat cell diameter đ. Indicated is the release in $\mathrm{nmol} / 10^{5}$ cells $/ 2 \mathrm{~h}$. Medium: KRB buffer, $4 \mathrm{~g} \%$ albumin, $5.55 \mathrm{mM}$ glucose, additions as in. 
between the two groups was observed. The "quotient of reesterification" Q (FFA release: glycerol release) was, however, significantly smaller in the obese subjects $(\mathrm{Q}=2.3 \pm 0.7)$ than in the controls $(\mathrm{Q}=3.3 \pm 1.3)$ $(p<0.001)$.

The release of metabolites per cell of part of those subjects was determined. It appeared that the basal metabolite release of the fat cell was about three times higher in obese persons than in the controls
The "dose" response relationship for norepinephrine, theophylline and DB-c-AMP was similar in normal weight and overweight subjects. Lipolysis was most effectively stimulated with DB-c-AMP and least with norepinephrine (Table 2).

When stimulation of lipolysis was expressed as \% of baseline, adipose tissue of obese subjects reacted less to norepinephrine, theophylline and DB-c-AMP. With one exception, the differences were statistically

Table 1. Basal glycerol and $F^{\prime} F A$ release of adipose tissue in $\mu$ mol/2 $h$ in normal and overweight, referred to $g$ tissue wet weight (wet weight), mmol esterified fatty acids ( $E F A$ ) and to $10^{5}$ cells, medium see legend to $F i g .4 a$, mean $\pm S D$

\begin{tabular}{|c|c|c|c|c|c|c|c|c|c|c|c|c|}
\hline \multirow{2}{*}{$\begin{array}{l}\text { Reference } \\
\text { system / } \\
\text { Subjects }\end{array}$} & \multicolumn{4}{|c|}{ Wet weight } & \multicolumn{4}{|c|}{ EFA } & \multicolumn{4}{|c|}{$10^{6}$ Cells } \\
\hline & $\bar{n}$ & Glycerol & FFA & $Q^{*}$ & $\bar{n}$ & Glycerol & FFA & $\mathrm{Q}^{*}$ & $n$ & Glycerol & FFA & $\mathrm{Q}^{*}$ \\
\hline Normal weight & 10 & $\begin{array}{l}0.41 \\
0.09\end{array}$ & $\begin{array}{l}1.4 \pm \\
0.5\end{array}$ & $\begin{array}{l}3.6 \pm \\
1.3\end{array}$ & 19 & $\begin{array}{l}0.23 \\
0.08\end{array}$ & $\begin{array}{l}0.73 \pm \\
0.30\end{array}$ & $\begin{array}{l}3.3 \pm \\
1.3\end{array}$ & 9 & $\begin{array}{l}0.22 \pm \\
0.13\end{array}$ & $\begin{array}{l}0.64 \pm \\
0.43\end{array}$ & $\begin{array}{l}3.3 \pm \\
1.6\end{array}$ \\
\hline Overweight & 11 & $\begin{array}{l}0.72 \pm \\
0.20\end{array}$ & $\begin{array}{l}1.5 \pm \\
0.5\end{array}$ & $\begin{array}{l}2.2 \pm \\
0.8\end{array}$ & 19 & $\begin{array}{l}0.34 \pm \\
0.14\end{array}$ & $\begin{array}{l}0.77 \pm \\
0.29\end{array}$ & $\begin{array}{l}2.3 \pm \\
0.7\end{array}$ & 8 & $\begin{array}{l}0.64 \pm \\
0.22\end{array}$ & $\begin{array}{l}2.27 \pm \\
0.64\end{array}$ & $\begin{array}{l}3.1 \pm \\
1.5\end{array}$ \\
\hline$p^{* *}$ & & $<0.01$ & ns & $<0.05$ & & $\mathrm{~ns}$ & ns & $<0.001$ & & $<0.001$ & $<0.001$ & $\mathrm{~ns}$ \\
\hline
\end{tabular}

$\mathrm{Q}^{*}=$ FFA release/glycerol release.

$p^{* *}=$ probability of differences in mean values, $\mathrm{ns}=$ not significant.

Table 2. Effect of norepinephrine $(0.1 \mathrm{\mu g} / \mathrm{ml})$, theophylline $\left(5 \times 10^{-3} \mathrm{M}\right)$, and $D B-c \cdot A M P\left(10^{-\mathbf{3}} M\right)$, in adipose tissue of normal- and overweight subjects (Mean $\pm S E M)$ on $F F A$ and glycerol release, medium see legend to $F i g$. $4 a$

\begin{tabular}{|c|c|c|c|c|c|c|c|c|}
\hline \multirow{3}{*}{ Subjects } & \multicolumn{8}{|c|}{ release in $\mu \mathrm{mol} / \mathrm{mmol}$ esteriefied fatty acids $/ 2 \mathrm{~h}$} \\
\hline & \multicolumn{2}{|l|}{ Basal } & \multicolumn{2}{|c|}{ Norepinephrine } & \multicolumn{2}{|c|}{ Theophylline } & \multicolumn{2}{|l|}{ DB-c-AMP } \\
\hline & Glycerol & FFA & Glycerol & FFA & Glycerol & FFA. & Glycerol & WFA \\
\hline $\begin{array}{l}\text { Normal weight } \\
(n=9)\end{array}$ & $0.23 \pm 0.02$ & $0.63 \pm 0.12$ & $0.57 \pm 0.09$ & $0.99 \pm 0.17$ & $0.62 \pm 0.08$ & $1.98 \pm 0.48$ & $1.54 \pm 0.21$ & $3.84 \pm 1.11$ \\
\hline $\begin{array}{l}\text { Overweight } \\
(n=8)\end{array}$ & $0.27 \pm 0.03$ & $0.65 \pm 0.7$ & $0.45 \pm 0.05$ & $0.89 \pm 0.09$ & $0.51 \pm 0.10$ & $1.20 \pm 0.16$ & $0.73 \pm 0.06$ & $1.56 \pm 0.09$ \\
\hline $\begin{array}{l}p^{*} \\
\text { release in } \% \text { of }\end{array}$ & $\begin{array}{l}\text { ns } \\
\text { baseline }\end{array}$ & ns & ns & ns & $\mathrm{ns}$ & $<0.05$ & $<0.005$ & $<0.025$ \\
\hline $\begin{array}{l}\text { Normal weight } \\
(n=9)\end{array}$ & 100 & 100 & $242 \pm 26$ & $195 \pm 37$ & $351 \pm 114$ & $430 \pm 98$ & $804 \pm 208$ & $675 \pm 177$ \\
\hline $\begin{array}{l}\text { Overweight } \\
(n=8)\end{array}$ & 100 & 100 & $171 \pm 15$ & $141 \pm 10$ & $226 \pm 45$ & $198 \pm 29$ & $282 \pm 29$ & $233 \pm 15$ \\
\hline$p^{*}$ & & & $<0.01$ & $<0.025$ & ns & $<0.005$ & $<0.005$ & $<0.025$ \\
\hline
\end{tabular}

$p^{*}=$ probability of differences in mean values, $\mathrm{ns}=$ not significant.

(Table 1). A significantly positive correlation existed between fat cell diameter and lipolysis (Fig. 4a and b). Differences in the quotient $Q$ were insignificant in this sub-group.

Norepinephrine, theophylline and DB-c-AMP stimulated lipolysis

The lipolytic effect of norepinephrine, theophylline and DB-c-AMP depended on the concentration in the medium (Fig. 5). Maximal effects were observed with $1 \mu \mathrm{g} / \mathrm{ml}$ norepinephrine and with $5 \times 10^{-3} \mathrm{M}$ theophylline. With DB-c-AMP an alternating reaction was observed. An increase in concentration up to $10^{-3} \mathrm{M}$ resulted in an augmented stimulation, whereas higher concentrations caused a decrease in stimulation. At $10^{-2} \mathrm{M}$ no significant lipolytic effect could be detected. significant (Table 2). The \% stimulation of glycerol and FFA release by DB-c-AMP was negatively correlated with the cell size (Fig. 6).

When FFA and glycerol release was calculated per mmol EFA, the absolute values of stimulated lipolysis were diminished in overweight subjects (Table 2). The release of metabolites by the individual cell, however, inereased with cell size. The correlation of lipolysis to cell diameter was significant for both FFA and glycerol and for the three lipolytic agents tested (Fig. 4a).

A described earlier (Thamer et al., 1969), addition of $5.55 \mathrm{mM}$ glucose to the incubation medium resulted in an increment in glycerol release and inhibition of FFA release; yet the relations between lipolysis and cell size were, in general, unaltered (Fig. $4 \mathrm{~b}$ ). 
- normal body weight

- obesity

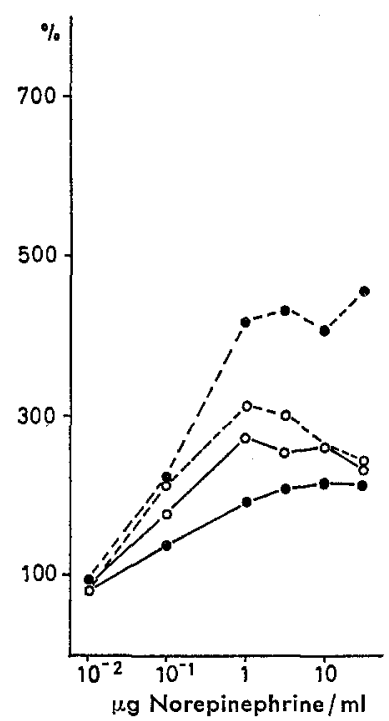

Glycerol

- - - FFA

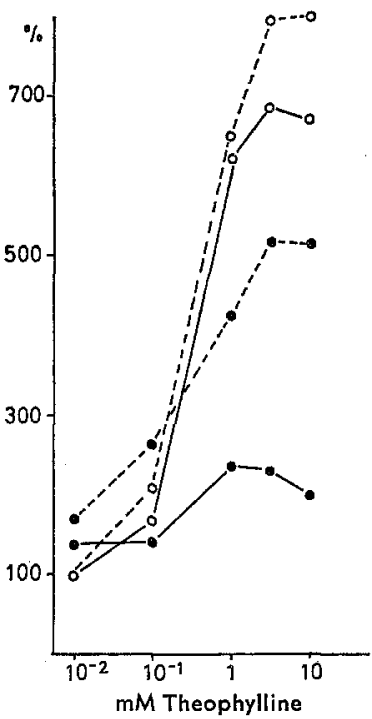

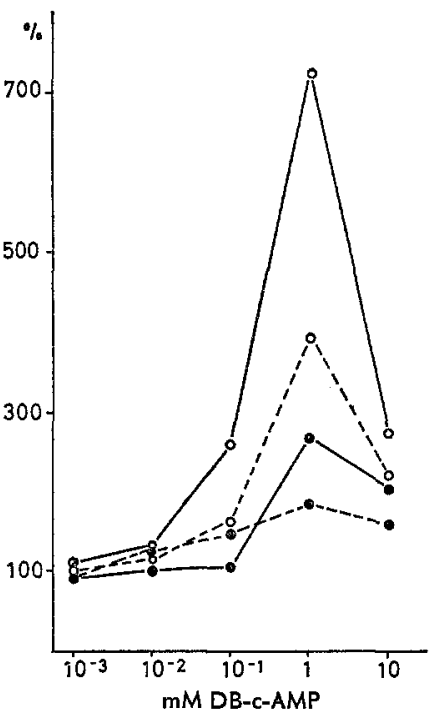

Fig. 5. Relationship between the concentration of norepinephrine, theophylline and dibutyryl-cyclic AMP in the medium and lipolysis in adipose tissue of normal weight and obese subjects. The release of glycerol and FFA is indicated as \% of baseline. Medium see legend to Fig. $4 \mathrm{a}, n=2$
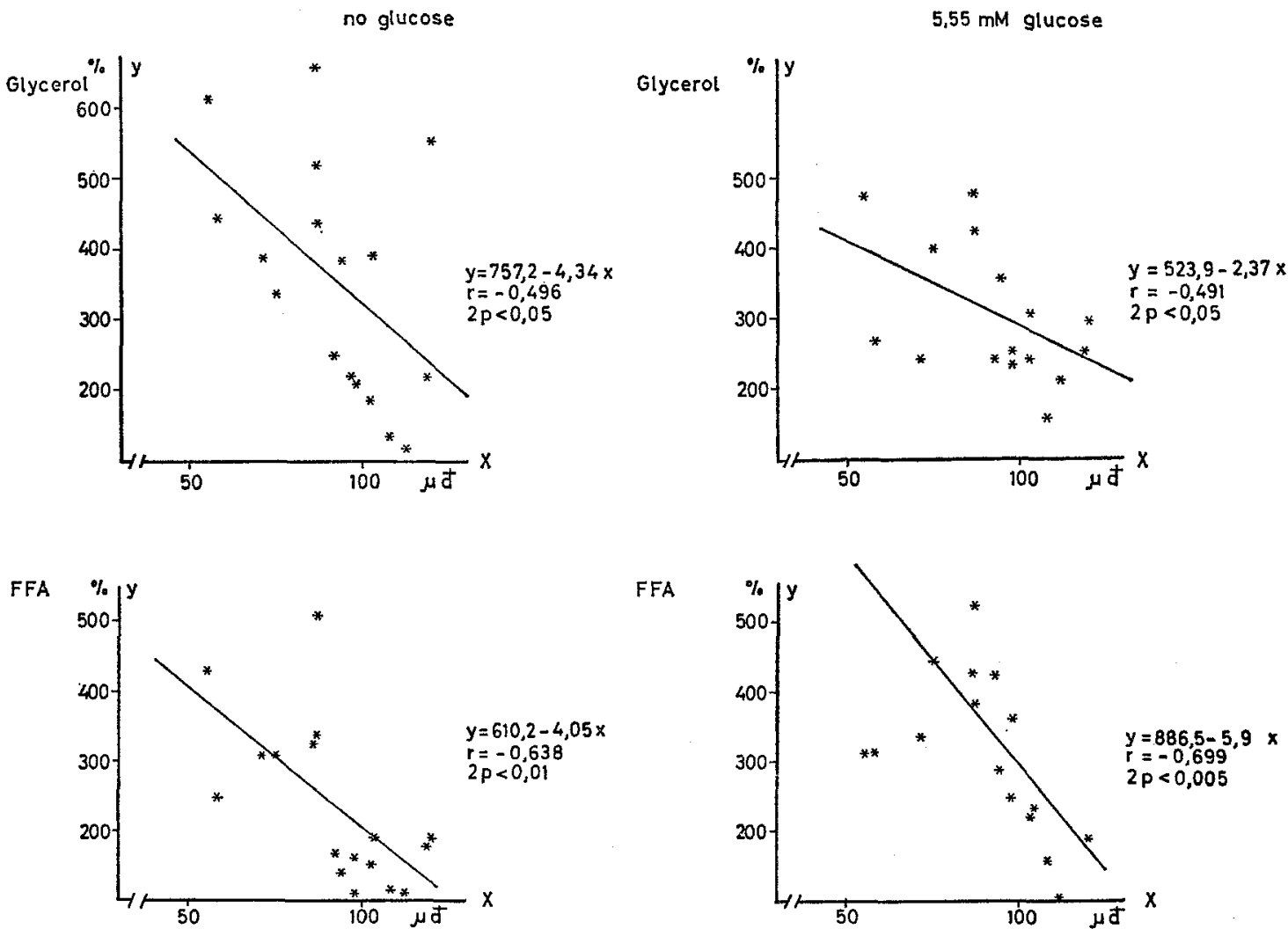

Fig. 6. Relationship between fat cell diameter and stimulation of lipolysis with $10^{-\mathbf{a}} \mathrm{M}$ dibutyryl-cyclic AMP. Indicated is the increase in glycerol and FFA release as \% of baseline. Medium see legend to Fig. $4 \mathrm{a}$ and $4 \mathrm{~b}$ 


\section{Discussion}

Some years ago several laboratories reported independently that the size of human subcutaneous fat cells increases with overweight (Hirsch et al., 1966; Preiss et al., 1967; Jahnke et al., 1967; Zinder et al., 1967). In contrast to a recent report of Goldrick and McLoughlin (1970) their findings have been confirmed by Faulhaber and co-workers (1969) and Hammermüller and co-workers (1970). The relation between cell diameter and relative body weight is, however, not linear (Hirsch et al., 1966; Faulhaber et al., 1969, Hammermüller et al. 1970) but of an exponential nature. Even in extreme obesity, the mean cell diameter of $135 \mu$ is generally not exceeded. On the basis of these observations it was demonstrated that in slight obesity the enhancement of body weight and adipose tissue mass can be explained by the increase in volume of the adipose cells (hypertrophy). However, in gross obesity the cell growth must be accompanied by an increase in the number of fat cells (hyperplasia) (Gries et al., 1970).

According to Mayer (1965) obesity of laboratory animals may be due to polyphagia (regulatory obesity) or to alterations in the regulation of metabolism (metabolic obesity). The question whether the metabolism of adipose cells is disturbed in human obesity has been examined repeatedly. Differences in the interpretation of the results seem to be partially due to different modes of calculation.

In earlier investigations the metabolic rates of adipose tissue were frequently referred to tissue wet weight. (Kahlenberg and Kalant (1964), Bergström and Carlson (1965), Owen et al. (1966), Preiss et al. (1968), Gries et al. (1968), Thamer et al. (1969)). However, in human adipose tissue the amount of fat cells per wet weight varies considerably. The DNA-content (Mosinger et al., 1965, Björntorp and Martinsson, 1966; Björntorp, 1967) represents the cell number of the sample (not considering polyploid cells which increase with age (Mohr and Beneke, $1968)$, but does not provide information on the proportion of adipose, mast and connective tissue cells. The fat-free dry weight and nitrogen content are often more influenced by connective tissue than by fat cells. This error is avoided if one refers to the lipid content as a measure of the adipose cell mass. However, due to the increased lipid content of large fat cells (Engelhardt et al., 1969), the number of adipocytes per mMol EFA is smaller in obesity than in normal weight. The differences obtained when evaluating the metabolic rate per lipid content or per cell number are shown in Table 1.

Previous experiments with norepinephrine have shown that the stimulation factor of lipolysis, i.e. increase of lipolysis in \% of base line, is reduced in obesity (Preiss et al., 1968; Thamer, 1969). This observation was confirmed in the present experiments and completed by similar findings with theophylline and DB-c-AMP. Differences in the dose response of lipolysis in normal and overweight people can be excluded as the cause (Fig. 5). It is also unlikely that the effect is due to hyposensitivity of the hormone receptors in the cell membrane or a disturbance of the intracellular synthesis of cyclic AMP, since direct stimulation of the lipase system with DB-c-AMP is decreasing with increasing cell diameter as well (Fig. 6).

The cause of the reduction of the stimulation factor could be either an absolutely increased basal lipolysis or a diminution of total lipase. We therefore measured the metabolite production of the individual cell. As the hormone sensitivity of isolated fat cells may be altered by treatment with collagenase during cellisolation (Gries and Steinke, 1967; Kono, 1969), the investigations were performed on tissue slices in which the number of fat cells had been determined.

In agreement with Faulhaber et al. (1969), the rate of lipolysis depended on the size of the fat cells. Under basal condition, as well as after stimulation of lipolysis, there were highly significant linear correlations between glycerol and FFA release and the cell diameter (Fig. 4a). Linear relations with cell volume, as reported by Goldrick and McLoughlin (1970) or cell surface, however, were not detectable. Since the relation of lipolysis to cell size was observed with norepinephrine as well as with DB-c-AMP (Fig. 4a), neither the hormone receptors in the cell membrane nor the intracellular cyclic AMP synthesis seem to be a substantial factor. It is more likely that the lipase content of the individual cell increases during cell growth. The increment of this enzyme system is less than the increment of the cell volume, which is consistent with the observation that in obesity the plasma space of fat cells also increases less than the cell volume (Englhardt et al., 1969).

Since in big cells the stimulation factor of lipolysis is decreased in spite of increased total lipase, it may be assumed that this phenomenon is due to a relatively greater basal lipolysis. Therefore, in obesity under basal conditions the relation of active lipase to inactive "prolipase" may be shifted in favour of the active enzyme. It has been suggested that this may be due to a higher basal activity of adenyl cyclase (Goldrick and McLoughlin, 1970). According to own findings (Thamer et al., 1969) and in accordance with Ho (1970) basal lipolysis is regulated by the energy supply of the lipocyte. However, in the present investigations, the relation of the stimulation factor to the cell diameter was not significantly influenced by glucose.

Previously, changes in the enzyme pattern of glycolysis and the pentose phosphate shunt have been described in obesity (Englhardt et al., 1969). The present experiments demonstrate additional changes in the lipase system. It remains to be settled whether these changes are a consequence of cell growth or due to other factors. Therefore, the possible pathogenetic significance of these changes in obesity remains speculative.

Acknowledgements: We gratefully acknowledge the evaluation of the correlations provided by Senior Public Health Officer, Dr. Breitbach. - The investigations were supported by Deutsche Forschungsgemeinschaft, Bad 
Godesberg, and Landesant für Forschung des Landes Nordrhein-Westfalen, Düsseldorf.

\section{References}

1. Berger, M. : Untersuchungen zur Lipolyse am menschlichen Fettgewebe in vitro. Medizinische Dissertation, Düsseldorf, 1970 .

2. Bergström, S., Carlson, L.A.: Inhibitory action of Prostaglandin $\mathrm{E}_{1}$ on the mobilization of free fatty acids and glycerol from human adipose tissue in vitro. Prostaglandin and related factors. Acta physiol. scand. 63, 195-196 (1965).

3. Björntorp, P.: The effect of insulin in vitro on human adipose tissue from normal and diabetic subjects. Acta med. scand. 181, 389-402 (1967).

4. - Hood, B.: Studies on adipose tissue from obese patients with or without diabetes mellitus. I. Release of glycerol and free fatty acids. Acta med. scand. 179, $221-227$ (1966).

5. - Martinsson, A.: The composition of human subcutaneous adipose tissue in relation to its morphology. Acta med. scand. 179, 475-481 (1966).

6. Bjurulf, P.: Atherosclerosis and body build with special reference to size and number of subcutaneous fat cells. Acta med. scand. 166, Suppl. 349, 1-99 (1959).

7. Englhardt, A., Gries, F.A., Liebermeister, H., Jahnke, $\mathrm{K}$. : Size, lipid and enzyme content of isolated human adipocytes in relation to nutritional state. Diabetologia 7, 51-58 (1971).

8. - - Preiss, H., Jahnke, K.: Vergleichende Untersuchungen über Protein und Lipidgehalt und Aktivitäten von Enzymen der Glykolyse und des Pentosephosphat-Shunts im Fettgewebe und in isolierten Fettzellen Stoffwechselgesunder. Horm. Metab. Res. 1, 228-234 (1969).

9. Faulhaber, J.D., Petruzzi, E.N., Eble, H., Ditschu. neit, H.: In vitro Untersuchungen über den Fettstoffwechsel isolierter menschlicher Fettzellon in Abhängigkeit von der Zellgröße: Die durch Adrenalin induzierte Lipolyse. Horm. Metab. Res. 1, $80-86$ (1969).

10. Folch, J., Lees, M., Sloane-Stanley, G.H.: A simple method for the isolation and purification of total lipids from animal tissues. J. biol. Chem. 226, 497509 (1957).

11. Goldrick, R.B., McLoughlin, G.M.: Lipolysis and lipogenesis from glucose in human fat cells of different sizes. Effects of insulin, epinephrine and theophylline. J. clin. Invest. 49, 1213-1223, (1970).

12. Gries, F.A., Berger, M., Oberdisse, K.: Untersuchungen zum antilipolytischen Effekt des Insulins am menschlichen Fettgewebe in vitro. Diabetologia 4, 262-267 (1968).

13. - Daweke, H., Liebermeister, H.: Diabetes mellitus bei Fettsucht. Verh. dtsch. Ges. inn. Med. 76, 51-72 $(1970)$

14. - Steinke, J.: Comparative effects of insulin on adipose tissue segments and isolated fat cells of rat and man. J. clin. Invest. 46, 1413-1418 (1967).

15. Hammermüller, B., Leonhardt, W., Hanefeld, M. Vorläufige Mitteilung über die elektrometrische IMes. sung der Volumenverteilungskurven isolierter menschlicher Fettzellen bei Adipositas und ihre Beziehungen zum Diabetes mellitus. Dtsch. Gesundh.-Wes. 25, $2020-2022(1970)$.

16. Hausberger, F.X.: Effect of dietary and endocrine factors on adipose tissue growth. In: Renold, A. E., and Cahill, G.F. jr., Eds.: Handbook of Physiology. Section V. Adipose tissue. Washington D.C. (1965) p. $519-528$.

17. Herberg, L., Hesse-Wortmann, C.: Personal communication.

18. -, Gries, F.A., Hesse-Wortmann, C.: Effect of weight and cell size on hormonal-induced lipolysis in New Zealand obese mice and American obese hyperglycemic mice. Diabetologia 6, 300-305 (1970).

19. Hirsch, J., Knittle, J., Salans, L.: Cell lipid content and cell number in obese and nonobese human adipose tissue. J. clin. Invest. 45, 1023 (1966).

20. Ho, R. J.: Dependence of hormone-stimulated lipolysis on ATP and cyclic AMP levels in fat cells. In: Jeanrenaud, B. and Hepp, D., Eds.: Adipose tissue. Regulation and metabolic functions. Georg Thieme, Stuttgart (1970) p. 83-87.

21. Itaya, K., Ui, M.: Colorimetric determination of free fatty acids in biological fluids. J. Lipid Res. 6, 16-20 (1965).

22. Jahnke, K., Daweke, H., Liebermeister, H., Schilling, W.H., Thamer, G., Preiss, H., Gries, F.A.: Hormonal and metabolic aspects of obesity in humans. Excerpta Medica, Intern. Congr. Ser. 172, 533-539 (1967).

23. Kahlenberg, A., Kalant, N.: The effect of insulin on human adipose tíssue. Can. J. Biochem. 42, 16231635 (1964).

24. Kono, T.: Destruction and restoration of the insulin effector system of isolated fat cells. J. biol. Chem. 244, $5777-5784(1969)$.

25. Kreutz, F.H.: Enzymatische Glycerinbestimmung. Klin. Wschr. 40, 361-363 (1962).

26. Mayer, J. : Metabolism of adipose tissue in experimental obesity. In: Renold, A. E., and Cahill, G. F. jr., Eds.: Handbook of Physiology. Section V. Adipose tissue. Washington D.C. (1965) p. 645-652.

27. Mohr, W., Beneke, G.: Age dependence of nuclear DNA-content of rat adipose tissue cells. Experientia 24, 1052-1053 (1968).

28. Mosinger, B., Kuhn, E., Kujalova, V.: Action of adipokinetic hormones on human adipose tissue in vitro. J. Lab. clin. Med. 66, 380-389 (1965).

29. Owen, J.A., Lindsay, R.W., Gaskin, J.H., Hollifield, G.: Response of human adipose tissue to endogenous serum insulin-like activity. Metabolism 16, 47-56 (1967).

30. Preiss, H., Hesse-Wortmann, C., Gries, F.A., Jahnke, K.: Die Größe menschlicher isolierter Fettzellen in Abhängigkeit vom Ernährungszustand. Dtsch. Ges. Fettwissenschaften, Tagung 1967, Fette, Seifen, Anstrichmittel 69, 827 (1967).

31. - Thamer, G., Gries, F.A., Solbach, H.-G., Jahnke, K. : Einfluß von Noradrenalin auf die Lipidmobilisation aus subcutanem menschlichem Fettgewebe in vitro bei normgewichtigen und adipösen Personen. Verh. dtsch. Ges. inn. Med. 74, 950-953 (1968).

32. Rodbell, M. : Metabolism of isolated fat cells. I. Effects of hormones on glucose metabolism and lipolysis. J. biol. Chem. 239, 375-380 (1964).

33. Reh, H.: Die Fettzellgröße beim Mensehen und ihre Abhängigkeit vom Ernährungszustand. Virchows Arch. path. Anat. Physiol. 324, 234-242 (1953).

34. Rosenthal, H.L., Pfluke, M.L., Callerami, J.: The colorimetric estimation of serum fatty esters. Clin. chim. Acta 4, 325 (1959).

35. Thamer, G., Preiss, H., Gries, F.A., Jahnke, K.: Zum Einfluß der Glukose auf die Lipidmobilisation aus subcutanem menschlichen Fettgewebe in vitro. $Z$. ges. exp. Med. 150, 94-100 (1969). 
36. - Die Noradrenalin-induzierte Lipolyse in isoliertem menschlichem Fettgewebe bei normgewichtigen und adipösen Personen. Med. Dissertation Düsseldorf (1969).

37. Vaughan, M.: The production and release of glycerol by adipose tissue in vitro. J. biol. Chem. 237, 33543358 (1962).

38. Zinder, O., Arad, R., Shapiro, B.: Effect of cell size on the metabolism of isolated fat cells. Israel J. Med. Sci. 3, 787-793 (1967).

Prof. Dr. F.A. Gries,

II. Medizinische Klinik

der Universität Düsseldorf

D.4000 Düsseldorf

Moorenstraße 5

Germany 